\title{
THE PERIODIC TABLE. ITS STORY AND ITS SIGNIFICANCE
}

\section{Ilmo. Sr. Editor,}

Foi com grande satisfação que tive a oportunidade de ler o livro The Periodic Table. Its Story and Its Significance de autoria de Eric R. Scerri, editado pela Oxford University Press (2007). Diferentemente do que se poderia imaginar a princípio, não é simplesmente um livro sobre os diferentes tipos de tabelas periódicas e sua evolução ao longo do tempo. O livro, dividido em dez capítulos, totalizando 286 páginas (excluídas as notas e referências), agrada não só pela sua organização e pelo texto fácil de ler, mas também pelo seu conteúdo que se aprofunda em diversas questões conceituais sobre química, física, filosofia da ciência e ciência em geral.

Seu autor, conceituado historiador da química e professor de história e filosofia da ciência na Universidade da Califórnia, campus de Los Angeles (UCLA), resgata em ricos detalhes os primeiros passos em direção ao estabelecimento desta que é um dos ícones da química e da ciência. Há quem já tenha proposto que ao se lançar naves espaciais para fora do sistema solar na tentativa de comunicação com outras formas de vida, não se pode deixar de incluir a tabela periódica como prova de que somos de fato uma forma de vida inteligente.

Voltando ao livro em si, Scerri nos mostra que, sem tirar o mérito de Mendeleev, muitos dos passos geralmente atribuídos exclusivamente a este, já haviam sido dados antes por outros, tais como as tríades de Döbereiner e as tabelas de De Chancourtois, John Newlands, Lothar Meyer e de outros menos conhecidos como William Odling e Gustavus Hinrichs. O seu resgate sobre a importância do trabalho de John Newlands é iluminador uma vez que este autor tem sido repetidamente ridicularizado por ter feito uma correlação dos períodos da tabela periódica com as sete notas musicais. Em artigo de 1863, publicado anonimamente e ainda ordenando os elementos usando os pesos atômicos anteriores à Conferência de Karlsruhe de 1860, Newlands já mostrava 11 grupos de elementos de propriedades análogas. Em seus dois artigos seguintes, de 1864, ele já emprega os pesos atômicos corretos (dentro das incertezas experimentais da época) mas atribuindo a cada elemento um número ordinal, como que se antecipando à noção moderna de número atômico. Mais importante que tudo, ele apresenta um sistema periódico indicando uma repetição de propriedades após certos intervalos regulares, que é a essência da lei periódica, além de inverter a sequência dos elementos iodo e telúrio, muitas vezes atribuída a Mendeleev.

Embora se possa imaginar que Scerri intente tirar o brilho de Mendeleev, no capítulo dedicado exclusivamente a este, toda a magnitude do trabalho de Mendeleev é enaltecida, dando ênfase ao seu maior preparo filosófico e seu apego à noção abstrata e aristotélica de elemento. Nas palavras de Scerri, "consideremos o exemplo comum do cloreto de sódio e o fato de que o metal sódio, cinza e veneno- so, e o cloro gasoso, verde e venenoso, aparentemente podem ser encontrados após reagirem quimicamente na forma de um composto cristalino branco, o cloreto de sódio". A capacidade de Mendeleev em considerar os elementos como entidades abstratas/metafísicas é que lhe permitiu enfrentar e superar o desafio de ordenar e agrupar os elementos de forma mais convincente que seus antecessores. Com isso, não só nesse capítulo, mas em outras partes do livro, Scerri se aprofunda nas diferenças conceituais entre substâncias simples (que podem ser isoladas e ter suas propriedades examinadas experimentalmente) e substâncias básicas (os elementos metafísicos que não podem ser observados). Entretanto, ele não deixa de citar que Mendeleev previu vários elementos que nunca foram encontrados, dentre eles o corônio e o éter, também chamados de elementos y e x, respectivamente, ambos com peso atômico menor que o do hidrogênio. Nesse contexto, é bastante gratificante observar a digressão de Scerri sobre a importância das capacidades de acomodação e previsão da tabela periódica e o papel de cada um desses conceitos na aceitação da lei periódica.

Para que não fique a impressão de que este livro trata apenas da parte histórica até Mendeleev é importante ressaltar que Scerri aborda de forma ampla a contínua evolução da tabela periódica até os dias de hoje, passando pelos trabalhos de Moseley, em espectroscopia de raios $\mathrm{X}$, que levaram ao conceito moderno de número atômico, à descoberta dos gases nobres, do núcleo atômico, da radioatividade e dos isótopos, e toda a evolução dos diferentes modelos atômicos e da mecânica quântica. É dado um significativo destaque ao debate sobre se a tabela periódica pode ou não ser explicada pela mecânica quântica a partir de conceitos físicos ab-initio, ficando para o leitor conferir o atual estágio desta disputa.

Claro que não poderia faltar uma abordagem sobre os diferentes formatos de tabela periódica até hoje propostos. Ao finalizar do livro, observa-se que Scerri toma posição em favor daquela originalmente proposta por Charles Janet em 1929, conhecida em inglês como left-step periodic table.

Enfim, trata-se de um livro de leitura obrigatória para todo professor de química de nível médio, para os que ministram química geral em nível universitário e todos aqueles apaixonados pela magia da tabela periódica dos elementos.

Roberto de Barros Faria Departamento de Química Inorgânica, Instituto de Química, Universidade Federal do Rio de Janeiro CP 68563, 21945-970 Rio de Janeiro - RJ, Brasil e-mail:faria@iq.ufrj.br 